\title{
Publisher Correction: Disease-relevant transcriptional signatures identified in individual smooth muscle cells from healthy mouse vessels
}

\author{
Lina Dobnikar ${ }^{1,2}$, Annabel L. Taylor (10 2 , Joel Chappell ${ }^{2}$, Phoebe Oldach ${ }^{1,6}$, Jennifer L. Harman², Erin Oerton (1) 1,7, \\ Elaine Dzierzak ${ }^{3}$, Martin R. Bennett ${ }^{2}$, Mikhail Spivakov (1D ${ }^{1,4,5}$ \& Helle F. Jørgensen (1) ${ }^{2}$
}

Correction to: Nature Communications; https://doi.org/10.1038/s41467-018-06891-x, published online 01 November 2018

The original version of this Article contained errors in the author affiliations.

Martin R. Bennett was incorrectly associated with Nuclear Dynamics Programme, Babraham Institute, Babraham Research Campus, Cambridge, CB22 3AT, UK. This has now been corrected in both the PDF and HTML versions of the Article.

Furthermore, Phoebe Oldach was incorrectly associated with Centre for Molecular Informatics, Department of Chemistry, University of Cambridge, Lensfield Road, Cambridge, CB2 1EW, UK.

This has now been corrected in the HTML version of the Article. The PDF version of the Article was correct at the time of publication

Published online: 17 December 2018

\begin{abstract}
(c) (i) Open Access This article is licensed under a Creative Commons Attribution 4.0 International License, which permits use, sharing, adaptation, distribution and reproduction in any medium or format, as long as you give appropriate credit to the original author(s) and the source, provide a link to the Creative Commons license, and indicate if changes were made. The images or other third party material in this article are included in the article's Creative Commons license, unless indicated otherwise in a credit line to the material. If material is not included in the article's Creative Commons license and your intended use is not permitted by statutory regulation or exceeds the permitted use, you will need to obtain permission directly from the copyright holder. To view a copy of this license, visit http://creativecommons.org/licenses/by/4.0/.
\end{abstract}

(c) The Author(s) 2018

\footnotetext{
${ }^{1}$ Nuclear Dynamics Programme, Babraham Institute, Babraham Research Campus, Cambridge CB22 3AT, UK. ${ }^{2}$ Division of Cardiovascular Medicine, University of Cambridge, Cambridge Biomedical Campus, Cambridge CB2 OQQ, UK. ${ }^{3}$ MRC Centre for Inflammation Research, University of Edinburgh, Little France Crescent, Edinburgh EH16 4TJ, UK. ${ }^{4}$ Functional Gene Control Group, Epigenetics Section, MRC London Institute of Medical Sciences, Du Cane Road, London W12 ONN, UK. ${ }^{5}$ Institute of Clinical Sciences, Faculty of Medicine, Imperial College, Du Cane Road, London W12 ONN, UK. ${ }^{6}$ Present address: Sir William Dunn School of Pathology, University of Oxford, South Parks Rd, Oxford OX1 3RE, UK. PPresent address: Centre for Molecular Informatics, Department of Chemistry, University of Cambridge, Lensfield Road, Cambridge CB2 1EW, UK. These authors contributed equally: Lina Dobnikar, Annabel L. Taylor. These authors jointly supervised this work: Mikhail Spivakov, Helle F. Jørgensen. The original article can be found online at https://doi.org/10.1038/ s41467-018-06891-x. Correspondence and requests for materials should be addressed to M.S. (email: mikhail.spivakov@lms.mrc.ac.uk) or to H.F.J. (email: hfj22@cam.ac.uk)
} 